\title{
COMPLEX ECOLOGICAL INFORMATIONAL SYSTEM'S DEVIATIONS AND THEIR OPTIMIZATION
}

\section{Yeremeyev}

Taurida National V. I. Vernadsky University

ORCID 0000-003-1968-0395

\section{A. Dychko, V. Lytvynenko}

National Technical University of Ukraine «Igor Sikorsky Kyiv Polytechnic Institute»

ORCID: 0000-0003-4632-3203; 0000-0002-4348-5832

Purpose. Concept of deviation as a quality estimation of complex ecological informational systems efficiency and their robustness ability is proposed. Deviations, their alternatives and their validity may be evaluated by means of heuristics, which operate mainly by fuzzy data and membership functions. Methodology. The deviations' evaluation methods of system, algorithm of its optimization and proper heuristics are submitted. The search of acceptable deviations in bounds of which the CCAS is capable for effective operating is extraordinarily significant task of up-to-data. As an example of deviation evaluation one can cite an analysis of CCAS behavior under conditions of sources and connectivity's alterations. Results. The main operation functions of CCAS are considered as admissible and their performability is satisfactory when the system remains in predicted extent or goes over to another legitimated predictive extent. This transition is transfer to alternative deviation - eventual way to implementation of installation-specific activity. Along this way there are the variety of problems due to information fuzziness and incompleteness on base of which it should be decision making relatively to identification of some satisfactory deviations. It is proposed an approach which facilitates to identify and to estimate principally possible alternative deviations i.e. the variety operable virtual CCAS capable by some way to achieve the functions which are entrust on them while their robustness should be guaranteed under conditions of possible structural and behavioral disturbances. Originality. A lot of attention in the world is paid to sustainable development concepts now. This concept implies the combination of natural and man-made cycles into a single system for the purpose of managing these cycles at the expense of «buffer» zones that exist objectively. Practical value. All processes of WW treatment are characterized by fuzzy specifications of parameters and variables which participate in the processes. Instead of clear-cut dependencies and models it is admitted to apply the heuristics with membership functions and suitable linguistic variables. References 10, figures 3.

Key words: complex, ecological, system, deviation, optimization.

\section{ВІДХИЛЕННЯ ТА ОПТИМІЗАЦІЯ В СКЛАДНИХ ЕКОЛОГІЧНИХ ІНФОРМАЦІЙНИХ СИСТЕМАХ \\ I. С. Сремсєв \\ Таврійський національний університет імені В. І. Вернадського \\ ORCID 0000-003-1968-0395}

\section{А. О. Дичко, В. А. Литвиненко}

Національний технічний університет України «Київський політехнічний інститут імені І. Сікорського»

ORCID 0000-0003-4632-3203; 0000-0002-4348-5832

Запропоновано концепцію відхилення як якісної оцінки ефективності складних екологічних інформаційних систем та їх надійності. Відхилення, їх альтернативи та їх обгрунтованість можна оцінити за допомогою евристики, яка діє переважно за допомогою нечітких даних та функцій належності. Представлено методи оцінки відхилень системи, алгоритм ії оптимізації та належну евристику. Пошук прийнятних відхилень, в межах яких CCAS здатний ефективно працювати, є надзвичайно важливим завданням оновлення даних. Як приклад оцінки відхилень можна навести аналіз поведінки CCAS в умовах джерел та змін зв'язку. Основні операційні функції CCAS вважаються допустимими, а їх ефективність є задовільною, коли система залишається в передбачуваному обсязі або переходить на інший легітимований передбачуваний рівень. Цей перехід переходить до альтернативного відхилення-можливого способу реалізації діяльності, специфічної для установки. На цьому шляху виникають різноманітні проблеми через нечіткість інформації та неповноту, на основі яких слід приймати рішення щодо виявлення деяких задовільних відхилень. Запропоновано підхід, який полегшує виявлення та оцінку принципово можливих альтернативних відхилень, тобто різноманітних функціональних віртуальних CCAS, здатних якимось чином виконувати функції, які на них покладаються, тоді як їх надійність повинна бути гарантована в умовах можливих структурних та поведінкових порушень. Зараз у світі багато уваги приділяється концепціям сталого розвитку. Ця концепція передбачає об'єднання природних і техногенних циклів в єдину систему з метою управління циклами за рахунок «буферних» зон, які існують об'єктивно. Усі процеси очищення стічних вод характеризуються нечіткими специфікаціями параметрів та змінних, які беруть участь у процесах. Замість чітких залежностей та моделей допускається застосування евристики з функціями належності та відповідними лінгвістичними змінними.

Ключові слова: комплексний, екологічний, системний, відхилення, оптимізація.

PROBLEM STATEMENT. The complex ecological computer-aided informational systems (CCAS) are characterized by capability of restoration their performance after wrong or unpredictable situations. Deviation - is the kind of passage (or passages' set) inside of which the system is allowed operating. CCAS staying in this passage is the warranty of system performance in principle. It is some analogy with error which corrupts the correct data but at the same time states a fact that the correct data are found in bounds of assured range. This 
deviation, this passage is always multidimensional one. It is formed by (min-max)-pairs which qualify the boundaries inside of which some parameters characteristic for the permissible regimes and behavioral characteristics exist [1-3].

As any complex informational system which deals with fuzzy data and uncertainity conditions, ecological systems operate with the limited retrievals of data and the laws of their distributing are unknown a priori. So here the methods with the use of the Bayes theorem, fuzzy set theory and linguistic estimations of researched data are used widely [4-5].

The main operation functions of CCAS are considered as admissible and their performability is satisfactory when the system remains in predicted extent or goes over to another legitimated predictived extent. This transition is transfer to alternative deviation - eventual way to implementation of installation-specific activity $[6,7]$.

The aim of the research is development of the algorithm of optimization of CCAS under real conditions with deviation considering.

MATERIAL AND RESULTS. As an example of deviation evaluation one can cite an analysis of CCAS behavior under conditions of sources and connectivity's alterations, as it is presented by "figure-of-eight" model (Fig. 1), which is proposed for modeling of biological, economic and social processes [8]. If the increase of SI resource (effectiveness) occurs simultaneously with the CI connectivity (complexity) increase that corresponds to the system's development SD, - the system operates adequately

If at any point in the trajectory (for example, A) there is a negative increase in the resource, it becomes a signal of an approaching crisis (CRA) and the need to carry out a local artificial crisis (LAC) for the purpose of adaptation (AD), that is, to look for deviance, to new conditions or risk-based requirements (VR). After that adaptation system may rise on higher level from point of view of resource and connectivity, i.e. scare up the adequately deviation. That provides the longer and more efficient system's operating in conservation mode (CM).

The above can be illustrated by the example of the complex ecological system of municipal solid waste (MSW) management. A lot of attention in the world is paid to sustainable development concepts now. This concept implies the combination of natural and manmade cycles into a single system for the purpose of managing these cycles at the expense of "buffer" zones that exist objectively (natural cycles) or the creation of technological cycles [9].

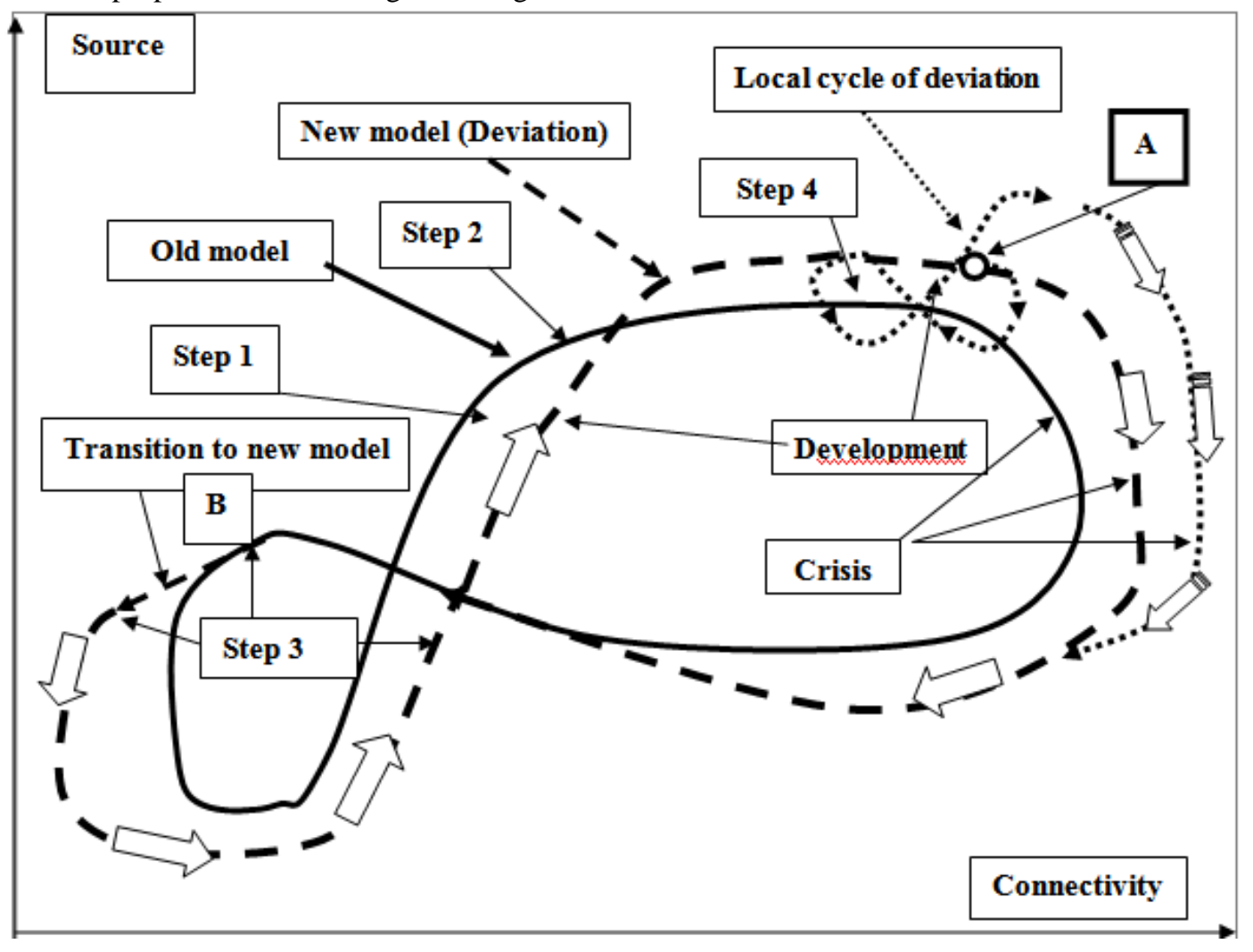

Figure 1 - CCAS operating when the old model disagrees with up-to-date objectives and the necessity to its replacement by search an optimal deviation exists:

Trajectory of the old model (steps 1and 2)

- - Trajectory of the new model (steps 3 and 4)

....... Trajectory of the local cycle (local «figure-of-eight»)

A - point on path where SI is negative as a result of local crisis;

$\mathrm{B}$ - point of transition to new model - step 3 (readjustment RA) 
The MSW treatment cycle involves combining natural and man-made buffer zones into a single system. In Phase 1, the MSW was dumped into landfills where, due to natural (physical, chemical and biological) processes, most MSW components were returned to their natural state, which provided the circulation of substances in nature. However, the volume of MSW increases annually, which threatens to turn large regions into continuous sources of environmental pollution, and the natural decomposition of MSW is a very slow process (the half-life of MSW decomposition is 50 years). When the landfill mass exceeded critical limits, Phase 2 of MSW management began - the construction of "landfills", which was characterized by fairly reliable isolation of MSW from the environment, as well as filtrate removal systems and the collection of gaseous MSW decomposition products for use as energy. But the number and capacity of the landfill sites continued to grow and a limit was approaching beyond which could not be increased. Therefore, it was necessary to move to a new model (Phase 3) - the construction of waste incineration plants (WIP), which provided the use of the organic constituent of MSW as a source of fuel resources. But WIPs use only about $50 \%$ of the organic constituents of MSW for energy generation. Therefore, now (Stage 4), combustion gas generators based on MSW pyrolysis are developing, which allow to use up to $90-95 \%$ of the organic components of MSW, as well as combined combustion and pyrolysis generators of heat and energy. At the same time, the MSW sorting system is being improved at all stages of treatment, with the aim of using individual MSW components as recyclables.

All processes of MSW treatment are characterized by fuzzy specifications of parameters and variables which participate in the processes. Because of that instead of clear-cut dependencies and models it is admitted to apply the heuristics with membership functions and suitable linguistic variables.

The above also can be illustrated by the example of the complex ecological system of development of aquatic ecosystems under the influence of chemical pollution. For example, the "eight" as a model of development of the aquatic ecosystem affected by wastewater from the production of nylon. The cycle of development of the aquatic ecosystem under the influence of wastewater of chemical industry enterprises containing hexamethylenediamine involves a combination of wastewater treatment process at the plant, before discharge into the reservoir and subsequent biological treatment in natural reservoirs. In phase 1 , wastewater is pre-treated at the plant, where a significant part of hexamethylenediamine is removed due to the physical and microbiological method of treatment. The treated water is discharged into natural reservoirs, and the HDM salm has a negligible impact on the fauna and flora. With a constant discharge of wastewater into a natural reservoir, HMD accumulates, phase 2 occurs. When the concentration of HMD in water increases, aquatic ecosystems do not withstand such an impact. Additional treatment and control of HMD concentrations in wastewater characterizes phase 3 . New technology of wastewater treatment from HMD for microbiological wastewater treatment within the technological scheme of the enterprise. Accordingly, the pressure on aquatic ecosystems decreases or remains at an acceptable level. Phase 4 provides for the complete removal of HMD residues in the wastewater of enterprises and discharge into natural reservoirs of drinking water, which does not have a negative impact on aquatic ecosystems.

The effective role of hydrological processes in water quality monitoring allows us to consider them as aquatic ecosystem management factor and develop mathematical systems for predicting water quality. By changing such elements of water mode as external and internal water exchange, water level, flow rate, etc., it is possible to shift the balance of self-cleaning processes self-contamination, thereby changing the chemical composition of water

The following heuristics are formulated to provide adaptation processes in the system:

$$
\begin{gathered}
I F([S I>\Delta \sigma I] A N D[I C>\Delta \sigma C]), T H A N(S D) ; \\
I F([S I \sim 0] A N D[I C>\Delta \sigma C], T H A N(K M) ; \\
I F([S I<-\Delta \sigma S] A N D[(I C<-\Delta \sigma C)], T H A N(C R A) ; \\
I F([S I>\Delta \sigma I] A N D[I C<-\Delta \sigma C], T H A N(R A) ; \\
I F([S I<-\Delta \sigma S] A N D[I C \sim 0], T H A N(A D) ; \\
I F([S I<-\Delta \sigma S] A N D[I C>\Delta \sigma C] A N D[V R \leq V R A c c], \\
\text { THAN }(L A C),
\end{gathered}
$$

where VRAcc - maximum allowed VR under real conditions, $\Delta \sigma \mathrm{S}$ and $\Delta \sigma \mathrm{C}-$ standard deviations respectively source and connectivity during acceptable operation of WW treatment system.

Another example of evaluation of adequately deviation is search the most appropriate model among the set of relevant ones which describes certain process (for example, the pollution migration). This search is based on "Nearest Neighbor" (k-NN) approach [10]. The essence of this approach is as follows (Fig.2):

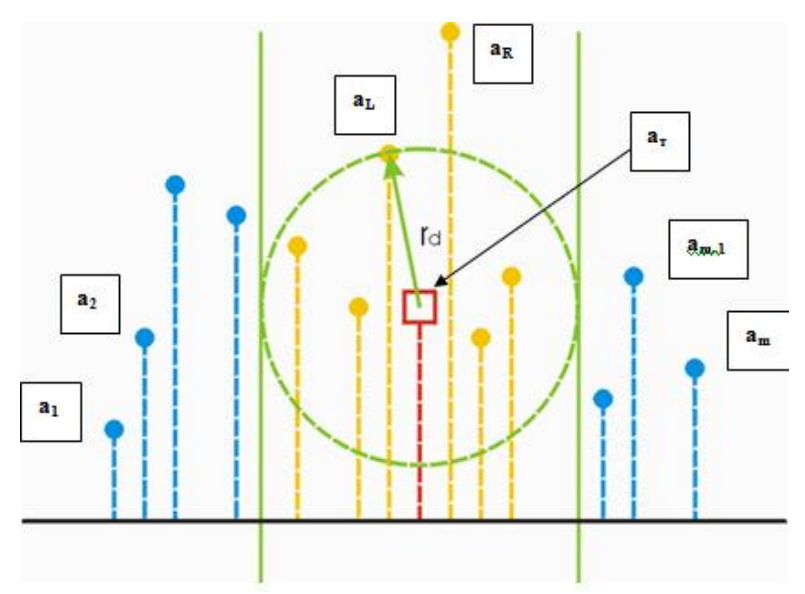

Figure 2 - Practical demonstration of algorithm k-NN

1. All points $a_{i}$ from data set are projected on one axis;

2. Tested point $\mathrm{a}_{\mathrm{T}}$ is also projected on this axis;

3. Search two nearest points (on the left $a_{L}$ and on the right $\mathrm{a}_{\mathrm{R}}$ from the testing point $\mathrm{a}_{\mathrm{T}}$ ); 
4. Measuring the distances between both prototypes (points), which are searched in step 3, and test of point and identification what distance is shortest $\left(\mathrm{r}_{\mathrm{d}}\right)$.

5. Calculation and saving in memory the distances (metrics) between $\mathrm{a}_{\mathrm{T}}$ and other points which arranged inside the circle of radius $r_{d}$.

6. Search the shortest distance in bounds of that set of points and find metrics that corresponds to the nearest neighbor $\mathrm{a}_{\mathrm{NN}}$.

If $\mathrm{k}>1$ it $\mathrm{s}$ necessary to turn away $\mathrm{a}_{\mathrm{NN}}$ found on preceding step and repeat $\mathrm{k}$ times steps from 2 to 6 . At the same time searched bounds $\left(r_{d}\right)$ are reappraised for the each new iteration, the new points-prototypes are appeared, but since the metrics on step 5 is saved, the only metrics which corresponds to new prototypes is calculated.

Using this algorithm we can determine the parameters of aquatic ecosystems. The algorithm takes into account the residual concentration of hexamethylenediamine in wastewater discharged into the reservoir and the parameters that characterize the aquatic envi- ronment. When using such an algorithm determine: species or population composition and quantitative ratio of species populations, abiotic conditions and resources inherent in this system, the totality of all connections, in the first - food chains, the ratio of organisms with different types of food, the size of primary and secondary products, spatial distribution of individual elements, speed of circulation.

Influence of separate hydrological parameters on the chemical composition of surface waters should be considered depending on the hydrological regime of water bodies.

If the deviations are inherent to CCAS, i.e. CCAS is capable to function at several different modes of operation with different sets of certain parameters and at the same time under different circumstances CCAS is capable to arbitrarily change its behavior, it should provide the opportunity of optimization this process by special algorithm.

That algorithm includes the following steps (Fig. 3):

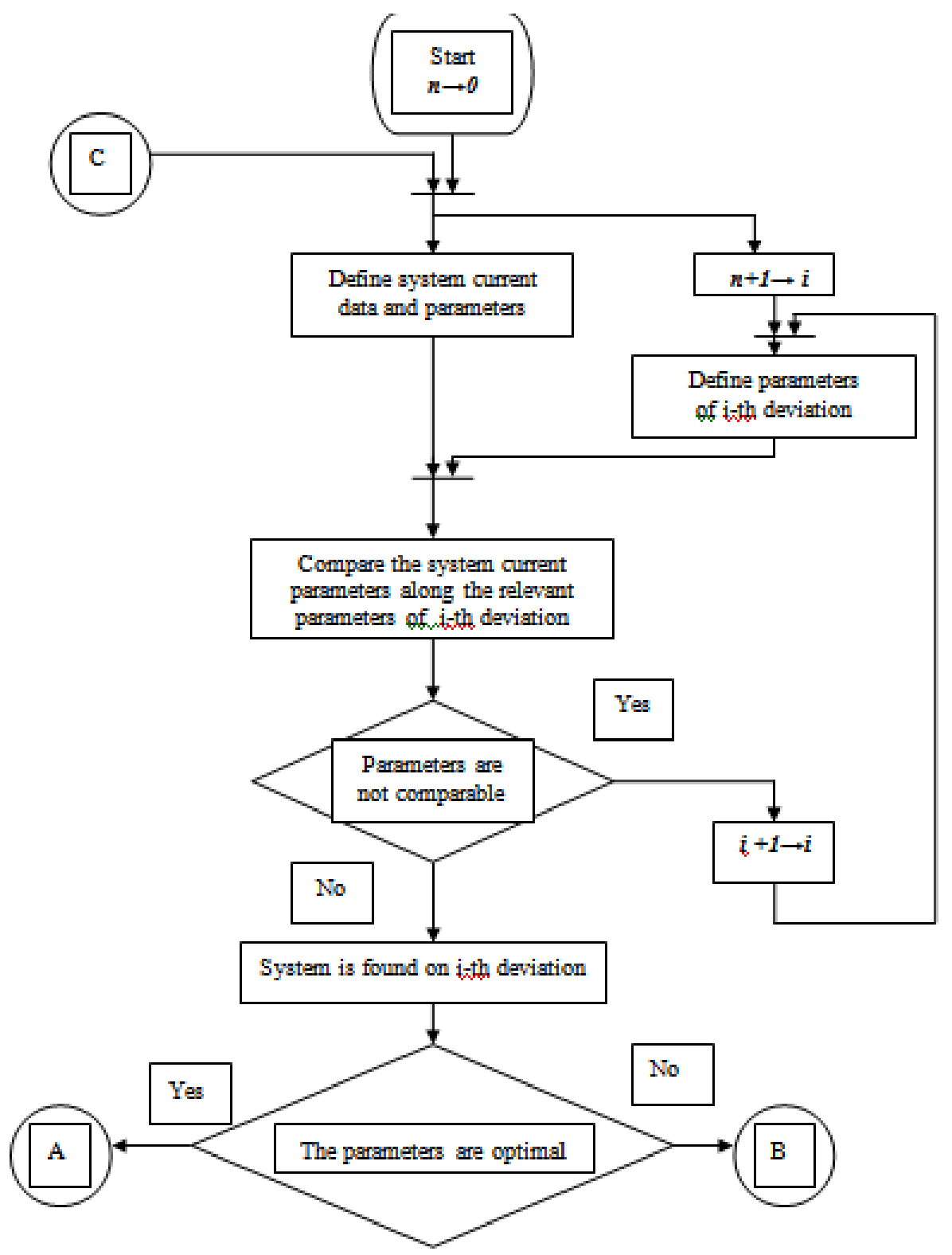

a) 


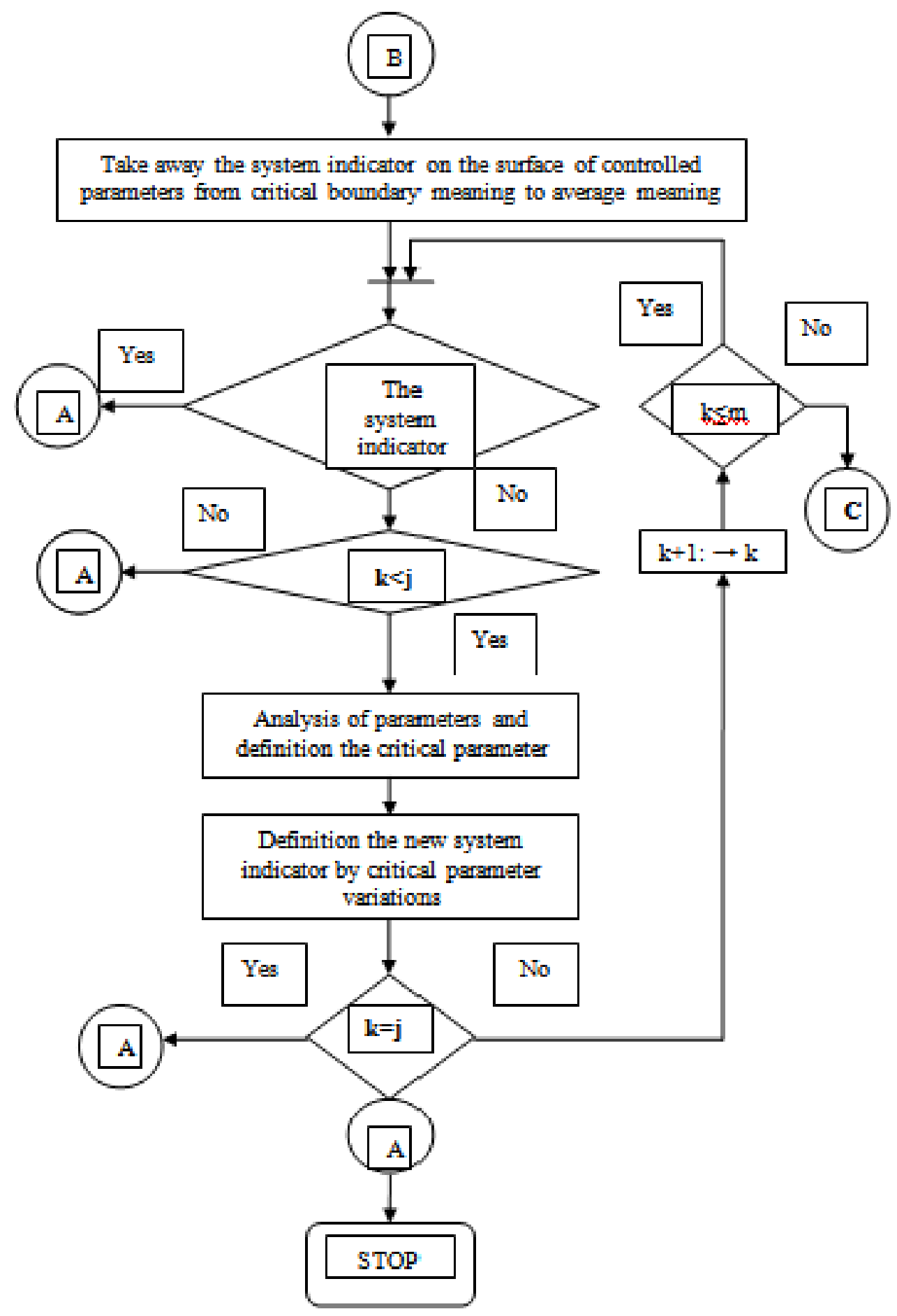

b)

Figure 3 - a) Deviation's optimization algorithm: $n$ - quantity of distinguished deviations; i - current deviation being considered; b) Deviation's treatment algorithm: $\mathrm{j}$ - controlled parameter;

$\mathrm{m}$ - maximal quantity of controlled parameters

1. At the beginning the identification of deviation in which CCAS is to be found must be realized.

2. After that step it is defined whether the deviation is optimal along the certain performances.

3. If there is a necessity (possibility) - CCAS transfer to optimal deviation occurs.

4. Along this step the optimization of parameters of picked out deviation is realized. CCAS may be on the boundary of deviation and it is necessary (if it is some possibility) to begin the process of selecting the parameters and their combination for the relocating CCAS from boundary to the middle of deviation.

5. Simultaneously it is essential to warning about situation when CCAS attempts to abandon the selected deviation.

Algorithms help to determine the optimal parameters and deviations in aquatic ecosystems. Providing a comprehensive approach to the study of the ecosystem. The 
study takes into account the following characteristics: saturated oxygen, $B O D_{5}$, concentration of hexamethylenediamine, $\mathrm{Cl}$, suspended solids, petroleum products and $\mathrm{pH}$.

The proposed algorithm realization provides the optimization of CCAS operating under broad spectrum of input signals and independent variable fluctuations.

CONCLUSIONS. The search of acceptable deviations in bounds of which the CCAS is capable for effective operating is extraordinarily significant task of upto-data. Along this way there are the variety of problems due to information fuzziness and incompleteness on base of which it should be decision making relatively to identification of some satisfactory deviations. It is proposed an approach which facilitates to identify and to estimate principally possible alternative deviations i.e. the variety operable virtual CCAS capable by some way to achieve the functions which are entrust on them while their robustness should be guaranteed under conditions of possible structural and behavioral disturbances.

Assurance of CCAS robustness and search acceptable deviations in bounds of which the systems is capable for effective operating is extraordinarily significant task. Along this way there are arised the variety of problems due to information fuzziness and incompleteness on base of which it should be decision making relatively to identification of some satisfactory deviations. It is proposed an approach which is based on Data Mining theory. The approach facilitate to identify and to estimate possible in principle alternative deviations i.e. the variety operable virtual CCAS capable by some way to achieve the functions which are entrust on them while their robustness should be guaranteed under conditions of possible structural and behavioural disturbances.

\section{REFERENCES}

1. Dhillon, B. S. (2002). Engineering maintenance: a modern approach. CRC PRESS LLC, N.W.

2. Sussman, G. J. (2008). Building Robust Systems, Massachusetts Institute of Technology.

3. Hoeting, J., Madigan, D., Raftery, A., Volinsky, C. (1999). Bayesian Model Averaging: A Tutorial, Statistical Science, 14(4), pp.. 382-401.

4. Karadimos, N. V., Orsoni, A. (2006). The role of modelling and simulation in design-build projects, Proceedings of the 20th European Conference on Modelling and Simulation.

5. Tai, A. T., Alkalai, L., Chau, S. N. (1999). Onboard preventive maintenance: a design-oriented analytic study for long-life applications, Performance Evaluation, 35, pp. 215-232.

6. Holling, C. S. (2001). Understanding the Complexity of Economic, Ecological and Social Systems. Ecosystems, 4, pp. 390-405.

7. Dychko, A., Yeremeyev, I., Remez, N. et al. Structural redundancy as robustness assurance of complex geoengineering systems E3S Web Conf., 166 (2020) 11003 DOI: https://doi.org/10.1051/ e3sconf/202016611003

8. Arlat, J., Kanoun, K., Laprie, J. (1990). Dependability modeling an evaluation of software-fault tolerant systems, IEEE Transactions on Computers. Special Issue on Fault-Tolerant Computing.

9. Cardinaels, E. (2018). Job allocation in large-scale networks with locality constraints, Eindhoven University of Technolog, Master Thesis, 69.

10. Beyer, K., Goldstein, J., Ramakrishnan, R., Shaft, U. (1999). When Is "Nearest Neighbor" Meaningful? Database Theory - ICDB’99, pp. 217-235.

Стаття надійшла 26.05.2021. 